\title{
Z BIOGRAFII KRÓLOWEJ JADWIGI
}

Wspominaliśmy ją zazwyczaj w rocznicę śmierci (17 VII 1399). Tradycję tę wprowadził przed wiekami Uniwersytet Krakowski, który w najbliższych latach po jej zgonie obchodził anniversaria, urządzał egzekwie. Mamy tego liczne przykłady: w r. 1401, 1411, później w 1420, 1425, 1428, 1440, 1443, 1477. Przemawiali wtedy uczeni profesorowie, jak Stanisław ze Skarbimierza, Jan Elgot, Mikołaj z Błonia, mistrzowie ,sztuk wyzwolonych", prawnicy, teologowie. Wiemy o tym z mów uniwersyteckich, dzięki pracom ostatnich lat ${ }^{1}$. Posiadamy informację $z$ drugiej połowy XV w., że król Kazimierz Jagiellończyk brał udział w egzekwiach urządzanych przez Uniwersytet $\mathrm{w}$ rocznicę śmierci Jadwigi ${ }^{2}$. Nie może więc być mowy o tym, aby Uniwersytet, a nawet dwór, rodzina królewska o Jadwidze zapomnieli, co nieraz jeszcze można usłyszeć czy przeczytać, a co nie zgadza się z nowszymi osiągnięciami nauki historycznej.

Jaki był stosunek żony Kazimierza Jagiellończyka, Elżbiety, do pamięci królowej Jadwigi, trudno stwierdzić, ale wydaje się wątpliwe, aby Elżbieta jako Habsburżanka, miała do niej rzekomo pretensje o zrezygnowanie $\mathrm{z}$ małżeństwa $\mathrm{z}$ Wilhelmem austriackim i nawet zahamowała kanonizację. Byłaby to duża nielojalność ze strony synowej Jagiełły, chociażby ze względów dworskich, i na to chyba nie pozwolono by na

1 Por. M. Kowalczyk, Krakowskie mowy uniwersyteckie $z$ pierwszej połowy XV $w$., Wrocław 1970; ks. Jerzy Wolny, Królowa Jadwiga w oczach współczesnych, ,Tygodnik Powszechny" nr 30 z 1969 (dotyczy 3 rękopisów znajdujących się w Bibliotece Jagiellońskiej, Bibliotece Seminarium Duchownego w Sandomierzu i Bibliotece Uniwersyteckiej we Wrocławiu). W "Acta Mediaevalia” (1973) ogłosiła uwagi nad mowa Elglota M. Szafarkiewicz.

2 Rachunki królewskie, opr. S. Gawęda, Z. Perzanowski, A. Strzelecka, „Materiały Komisji Nauk Historycznych PAN, Oddział w Krakowie" 2 (1960) 146. „Item feria quinta ipso die s. Alexii [17 VII 1477] doctoribus et magistris universitatis celebrantibus exequias olim serenissime domine Hedvigis regine Polonie, ser. domino regi dedi pro offertorio exequiarum tres fert [...] acta sunt Cracovie" (tamże 164). 
polskim dworze ${ }^{3}$. W korespondencji Długosza znajduje się natomiast zdanie, że pieniądze mogące służyć staraniom o kanonizację królowej Jadwigi zostaly jakoby roztrwonione. Przemawia raczej do przekonania sąd, że pieniądze, które spodziewano się uzyskać z funduszów państwowych na kanonizację Jadwigi w r. 1450, utonęły wkrótce w potrzebach wojny 13-letniej z Krzyżakami o Pomorze ${ }^{4}$. Istotnie król ściągnął na ten cel zewsząd wpłaty i pożyczki, znoszono wiele braków na Wawelu, latami spłacano zaległy żołd wojskom zaciężnym.

Wznowione za naszych czasów starania o kanonizację Jadwigi zbliżyły społeczeństwo polskie jeszcze bardziej do jej sarkofagu w katedrze wawelskiej; modlą się swoi i obcy (często widać szarfy węgierskie), składają wota, jak to czyniono wkrótce po jej śmierci. Już kaznodzieja uniwersytecki z 1 połowy XV w. pozostawił nam świadectwo, że przy grobie Jadwigi - wówczas więc przy głównym ołtarzu, obok ufundowanego przez nią niewiele przed śmiercią ołtarza św. Brygidy i św. Erazma, dziś nieistniejącego - widać zawieszone ,woskowe figury" 5 .

Dla pokolenia naszych rodziców, a i dla nas samych we wczesnej młodości, królowa Jadwiga z okresu, kiedy przybywała do Polski, była nie dzieckiem, ale młodziutką dziewczyną, zakochaną, wkrótce zawiedzioną. Uchodziła przez pół tysiąca lat kultu i zainteresowań historycznych za starszą o lat 3 niż była w istocie, za urodzoną nie w r. 1374, ale w 1371. Przypomnijmy, co powiedział o jej wieku J. Dąbrowski w książce o ojcu Jadwigi, gdzie rozstrzygnął daty urodzin jego córek ${ }^{6}$ : ,ZŹródła węgierskie przemilczają daty urodzin wszystkich trzech córek Ludwika [...] Pozornie zdaje się rozstrzygać sprawę Długosz, który oznacza datę urodzin Katarzyny na r. 1358, Marii na r. 1365, a Jadwigi na r. 1371 (Historia III 272, 306, 348) [...] Fakty atoli tym razem przeczą zupełnie przekazowi Długosza i zmuszają nas do innego postawienia sprawy [...] W maju 1366 r. Elżbieta [bratanica Ludwika] jest dziedziczką Węgier [...] Dokument Ludwika wy-

3 Co prawda w Rachunkach, które niejednokrotnie notują kwoty wydawane przez podskarbiego rodzinie królewskiej, nie ma wzmianki przy rocznicy Jadwigi ani o królowej Elżbiecie, ani o dzieciach, jak bywa przy innych okazjach: „domino regi [...] ac d. regine ac natis sue serenitatis dedi pro offertorio [...]". Udzielenie Elżbiecie kwoty pro offertorio [die] dominico proximo ante Hedvigis [13 X 1476] także nie upoważnia do sądu, że myślała ona o królowej Jadwidze w niedzielę przed świętem jej patronki (tamże 156).

4 List Dlugosza do Zbigniewa Oleśnickiego z 5 II 1450 w Codex epistolaris saec. XV (Monum. med. aevi hist., t. 2, p. 2), 104: „De canonisatione beate Hedvigis regine modica apud me est spes, supervacue verberamus aerem. Non est enim spes ut pecunie contributionis ad illum deputaretur usum, quarum maior pars iam distracta est". Por. Wanda Maciejewska, Jadwiga królowa polska, Kraków 1934, 169 .

5 ,Hoc ipsum est figure ceree supra tambulum eius dependentes liquide demonstrant et velut signa effectum vite eius pristine indicant sanctitatem". - Mieczysław Gębarowicz, Psałterz floriański i jego geneza, Wrocław 1965, 16. Tekst kazania znalazła M. Kowalczyk w Bibl. Jagiell,, rkps 1272 i 2372.

" Jan Dąbrowski, Ostatnie lata Ludwika Wielkiego, Kraków 1918, 16 n. 
stawiony w Koszycach dn. 3 października 1373 dla miasta Poznania za uznanie prawa córek jego do dziedziczenia tronu w Polsce [...] powiada [...] wyraźnie, że Poznań złożył hołd tak córkom jego Katarzynie i Marii, żyiącym w tej chwili, jak potomkom obu płci później przyjść na świat mającym, zaznaczając raz jeszcze, że tylko owe wymienione córki posiada [...] przeto widocznem jest, że Jadwigi nie było na świecie i urodzenie jej przypada na czas po 3 października 1373 [...] Na 1370 przypadają urodziny pierwszej córki Katarzyny [...] Maria kończyła lat 12 w r. 1383, ona więc, nie Jadwiga urodziła się w r. 1371". Tę datę roczną: koniec 1373 r. dla Jadwigi, rozwinięto i uzupełniono $z$ dużym prawdopodobieństwem na 18 lutego 1374 na podstawie autopsji zapisek w Kalendarzu Krakowskim, dotyczących zaręczyn z Wilhelmem, koronacji i ślubu Jadwigi i Jagiełły oraz ogólnych danych i dat związanych z pełnoletnością Jadwigi, czyli ukończenie przez nią 12 lat. Dzięki więc J. Dąbrowskiemu i A. Bocheńskiej, posiadamy obecnie datę urodzin Jadwigi, choć expressis verbis nie podało nam jej żadne znane dotychczas źródło ${ }^{7}$.

Data ta ma dla jej dziejów szczególne znaczenie, wcale nie czysto formalne; stwierdza ona, że Jadwiga była rzeczywiście dzieckiem, kiedy zarysowywały się jej losy i kiedy stanęła u progu jakoby samodzielnych rządów w Polsce. W roku 1374, przeznaczył ją ojciec układem z ksiązętami habsburskimi, wkraczającymi w okres swego wzrostu i znaczenia w Europie, na żonę księcia Wilhelma, wówczas kilkuletniego dziecka. Kiedy Jadwiga miała lat 4 zaślubiono te dzieci zwyczajem średniowiecznych rodzin panujących, tzn. małżeństwem „na przyszłość”, a Jadwigę mającą panować z Wilhelmem w Austrii, wysłano na dwór do Wiednia. Wróciła o wiele wcześniej niż przewidywano (prawdopodobnie w pierwszej polowie 1379 r.), a to z powodu śmierci najstarszej królewny węgierskiej Katarzyny i zaistniałego nowego układu politycznego na dworze Ludwika ${ }^{8}$. Już nie Austria, ale bogate Węgry, cel dążeń dynastii europejskich, miały stać się dziedzictwem Jadwigi i Wilhelma, przeznaczane poprzednio królewnie Katarzynie z królewiczem francuskim. Maria z Zygmuntem Luksemburskim od początku przeznaczani byli na panujących w Polsce, głównie ze względu na pochodzenie Zygmunta wprost od Kazimierza Wielkiego, przez jego córkę i wnuczkę, dwie Elżbiety pomorskie. Jak wiemy, plany króla Ludwika przekreśliła jego śmierć w r. 1382. Tymczasem zaś zięciom niemieckim niechętna była matka Jadwigi, piękna i żądna władzy Elżbieta córka Piastówny i bana Bośni, zwana u nas Bośniaczką, żyjąca długie lata w cieniu męża i jego matki, Elżbiety Łokietkówny. Kiedy na Węgrzech okrzyknięto Marię królem, a Polacy nie godzili się na perso-

7 Anna Misiąg-Bocheńska, Dwie daty $z$ życia królowej Jadwigi, „Polonia Sacra" 2 (1949) 268-75.

8 J. Dąbrowski, dz. cyt., 361 n., 369. 
nalną unię z Węgrami, po pertraktacjach z królową wdową węgierską, Jadwiga, jako mogąca stale zamieszkać w Polsce, została na jej królowę przez matkę przeznaczona ${ }^{9}$. Pierwszym aktem, znanym od niedawna, włączającym Jadwigę do stosunków polskich, jest dokument, w którym Jadwiga występuje w r. 1383 jeszcze z Węgier wraz z matką w sprawie obsadzenia probostwa w Bochni; jest tam nazwana ,następczynią w królestwie polskim pana Ludwika króla [...] prawdziwą i uprawnioną oraz dziedziczką królestwa polskiego" 10. Wkrótce, za Jadwigi oczywiście niewiedzą, panowie polscy, dyplomaci głównie małopolscy, zadzierżgiwali porozumienie z w. księciem litewskim Jagiełłą, widząc w nim i sojusznika wobec wroga wspólnego, Krzyżaków, i męża królowej. Wydaje się, że ezynili to bez rozgłosu, nie zaprzeczając planom Habsburgów, wobec których nie mieli żadnych zobowiązań. Ale zbliżała się sprawa dojrzałości Jadwigi, owe 12 lat wieku, i książę Leopold austriacki nie zaniedbywał perspektywy małżeństwa syna już de praesenti, obecnie nie z królewną posiadającą prawa do dziedziczenia po ojcu, ale z koronowaną (na króla) królową. Tak więc kiedy w Krewie 14 sierpnia 1385 r. oznajmiał Jagiełło swą wolę poślubienia królowej polskiej 11, prawie równocześnie stanął w Krakowie książę Wilhelm pod opieką ambasadora królowej węgierskiej Elżbiety, symulującej dotrzymanie dawnych umów Ludwika. W orszaku Opolczyka znajdował się $\mathrm{m}$. in. rycerz Gniewosz z Dalewic i Wilhelm zamieszkał w podwawelskim dworze Gniewosza ${ }^{12}$; usiłowali oni opanować zamek wawelski, doprowadzić do realizacji małżeństwa. Wiemy już o spotkaniach dziecięcej pary u franciszkanów, o tym, że mimo wielu pozorów i dwu różnych wersji Długosza nie dopuszczono do spełnienia małżeństwa między 11-letnią królową, a o kilka lat starszym od niej narzeczonym, co szczególnıe wyraźnie stwierdza Ludolf, opat kanoników regularnych

9 Por. W. Maciejewska, dz. cyt., 23; Elżbieta, żona Ludwika [W:] PSB VI 246-8.

10 Zbiór dokumentów katedry $i$ diecezji krakowskiej, cz. 1 1063-1415, wyd. S. IKuraś, Lublin 1965, 128: Wyznaczony przez biskupa Radlicę sędzia odbiera (między $17 \mathrm{X}$ a $17 \mathrm{XII} 1383 \mathrm{w}$ Krakowie) probostwo w Bochni plebanowi osadzonemu tam przez Zygmunta Luksemburskiego w czasie, kiedy ten usiłował utrzymać się w Polsce i przysądza tę parafię komu innemu, kogo poleciła Elżbieta, ,regina relicta [...] mater et tutrix generose principis domine Hedvigis [...] successoris in regno Polonie domini Lodovici regis [...] heredis Polonie regni".

11 Nie wspomniano tam o chęciach Jadwigi. Bierna rola Jadwigi-dziecka uwidoczniła się szczególnie w późniejszym akcie wydanym w Wołkowysku 11 I 1386 przez panów polskich: „Pactavimus ita quod ipsum pro domino et rege regni videlicet Poloniae [...] praelegimus sibi quoque inclitissimam Hedvigem et praeclaram principem Poloniae naturalem in coniugem legitimam conditione matrimoniali dedimus, condonamus, conferimus et contulimus copulandam. Quam quidem nostram ordinationem et definitionem [...] et contractum ... ab omnibus regnicolis regni promittimus et spondemus rata, grata et inviolabiliter fore conservanda" Akta unii Polski z Litwa 1385-1791, wyd. S. Kutrzeba, W. Semkowicz, Kraków 1932, $\mathrm{nr} 2$.

12 A. Strzelecka, Z przesztości powięziennych gmachów św. Michała w Krakowie, „Biuletyn Historii Sztuki” 18 (1956) nr 2. 
w Żaganiu, w swej Kronice ${ }^{13}$. Na wytoczony przez siebie proces w kurii Habsburgowie się nie stawili, sprawa wygasła, choć podsycana była stale w opinii europejskiej propagandą krzyżacką ${ }^{14}$.

Jadwiga w Polsce jakoby rządziła od jesieni 1384 roku. W jej imieniu wydawano dokumenty, załatwiano sprawy państwowe. Niewielu z nich można przypisać wkład własnej woli i jakieś zrozumienie dziecięcej królowej. Należy do nich akt jej kancelarii, którym obdarowała dochodem w okresie swych pierwszych Swiąt Bożego Narodzenia w Polsce, ołtarz Matki Boskiej w katedrze 15. Jeśli tu nawet trzeba widzieć wskazówkę starszych - ,zasięgnąwszy dojrzałej rady naszych baronów”, a zwrot ten w odniesieniu do Jadwigi ma zupełnie realne znaczenie, nie kancelaryjno-kurtuazyjne - to akt ten nie przechodził zrozumienia królowej wówczas dziesięcioletniej. Z domu rodziców wyniosła szczerą religijność, prawdopodobnie kult Maryjny ${ }^{16}$, żyła w kręgu darowizn na rzecz Kościoła i fundacji rodziców i babki na Węgrzech.

Nie mogła natomiast mając lat 12 rozumieć w pełni znaczenia odwołania dawnych ślubów, tzw. hainburskich z Wilhelmem, odwołania, którego dokonała $w$ katedrze przed ślubem z Jagiełłą. Ale wspomnieć tu warto, że jeden $z$ naszych czołowych mediewistów postawił był pytanie, czy nie stosunek do własnej matki, a nie do Wilhelma czy do Jagiełły, decydował o uczuciach Jadwigi ${ }^{17}$; można by więc sądzić, że to co wydaje

13 J. Dąbrowski, Królowa Jadwiga, „Przegląd Powszechny” 50 (1933). Misiąg-Bocheńska zwróciła uwagę w art. cyt., że dążenie księcia Leopolda austriackiego, który wysłał syna do Krakowa celem doprowadzenia do realizacji małzeństwa z Jadwigą, mimo że latem 1385 r. nie ukończyła ona jeszcze 12 lat, miało ewentualną podstawę prawno-obyczajową, „furtkę", z której zapewne w grze o tron polski zamierzano skorzystać.

$14 \mathrm{~W}$ artykule o Jadwidze w Hagiografii polskiej, t. 1., Poznań 1971, 498 opuszczono niestety (błąd drukarski?) słowo ,nie”, z czego wynikła fałszywa informacja, jakoby Habsburgowie stawili się na wytoczony przez siebie proces $w$ Kurii Rzymskiej.

${ }_{15}$ Potwierdziwszy najpierw przywileje Kazimierza Wielkiego dla tego ołtarza: „nosque ad virginem benedictam [...] devotionem gerimus specialem [...] habitoque prius maturo consilio baronum nostrorum" Kraków, 28 XII 1384. - Kodeks dyplomatyczny katedry krakowskiej (Monum. med. aevi hist., t. 8, p. 2), ed. F. Piekosiński, Cracoviae 1883, 102.

16 Krystyna Pieradzka, Fundacja klasztoru Jasnogórskiego $w$ Częstochowie w 1382 r., Kraków 1939. Autorka domyśla się, że z woli króla Ludwika książę Władysław Opolski założył klasztor Paulinów w Częstochowie. Ewa Śnieżyńska-Sołot postawiła hipotezę, że Jadwiga przywiozła ze sobą do Polski i darowała kościołowi częstochowskiemu obraz Matki Boskiej, który Elżbieta モokietkówna otrzymała kiedyś we Włoszech i testamentem ofiarowała go synowej, a ta córce wyjeżdżającej do Polski - Geneza, styl i historia obrazu Matki Boskiej Częstochowskiej, „Folia historiae artium" 9 (1973).

17 Por. Stanisław Zakrzewski, Wypadki lat 1382-6. W zwiazku z genezq unii, w: Pamiętnik V Zjazdu Historyków Polskich w Warszawie, Warszawa 1930. Podmiotem wydarzeń dynastycznych na Węgrzech i w Polsce w 1. 1382-6 nie były Maria i Jadwiga, lecz osoba ich matki Elżbiety Bośniaczki, która przeciwstawiała się niemieckim ideom spadku pozostawionego przez Ludwika. Warto by się zastanowić czy Elżbieta i wielka księżna litewska nie są właściwymi inicjatorkami małżeństwa swych dzieci (tamże, 352). Myśl tę, jeśli idzie o księżnę Juliannę, roz- 
nam się tragiczne, jak wówczas głosili wrogowie unii - wyrzekanie się narzeczonego w 12 roku własnego życia - nie miało wymowy dla małej królewny. Podniecana przez starszych, złapała za topór, to chyba prawda, kiedy zobaczyła, że ją, królowę, otoczono strażą; ciosy w furtę wawelską były istotnie dziecinne, ale dla polskiej racji stanu niebezpieczne, jeśli się zważy, że baza Wilhelma, dwór Gniewoszowy, znajdował się tuż pod Wawelem ${ }^{18}$. Pohamowała się jednak, kiedy jej zapewne wyjaśniono, przypuszczalnie wpierw nim przypomniano o chrzcie Litwy, że tego istotnie życzy sobie jej matka, wbrew koniecznym pozorom poparcia Wilhelma. Osłabienie dramatu Jadwigi z r. 1385/6 nie jest obniżaniem jej świętości; gdzie indziej bowiem należy tej świętości szukać, nie na drodze niezrozumiałych dla niej targów politycznych, kiedy miała lat 10, 11 czy 12, ale w tym, kim stawała się świadomie z biegiem lat. Wstrząsający pozostaje fakt, że naprawdę nie wiedziała, co czyniła, choć nikt nie może być pewnym, że droga, z której ją zawrócono, miała być właśnie w sensie ludzkim szczęśliwa. Sprawę chrztu Litwy pięknie przedstawił książę Skirgiełıło, kiedy w imieniu brata prosił był uroczyście (w styczniu 1385) na Wawelu o rękę Jadwigi i kiedy powiedział: „Od dawna potężni władcy upraszali księcia Jagiełłę o porzucenie wiary przodków dla religii chrześcijańskiej, ale on nie dawał się nakłonić ani namową, ani ustawiczną o to wojną z Krzyżakami. Dla niej przeznaczył Bóg tę chwałę, która trwać będzie na wieki" 19 .

W roku swego ślubu (1386) Jadwiga i Jagiełło wyjechali wiosną do Wielkopolski $\mathrm{w}$ ważnych celach wewnętrzno-politycznych. Z tej podróży — ,jak mówią", zanotował Długosz - pochodzić mają słowa Jadwigi ,kztóż im łzy powróci?" 20 w odniesieniu do chłopów pokrzywdzonych przez

winąl w powieści historycznej Litwin i Andegawenka Stefan M. Kuczyński (Katowice 1974).

18 Skoro dwór Gniewoszów znajdowal się tuż pod Wawelem, to atak na zamkniętą furtę mial swoją rację, co rozumialo zapewne otoczenie Jadwigi; zarówno ci, którzy byli przychylnie usposobieni do Wilhelma, jak i politycy, którzy furtę zamknęli (Strzelecka, Z przeszłości...). Ostatnio jeden z historyków zwrócił uwagę, czy nie należy w ogóle zakwestionować relacji Długosza o rąbaniu furty przez Jadwigę i włączyć ten obraz do całości propagandy krzyżackiej w jej antyunijnym nastawieniu (Józef Garbacik, Jadwiga Andegaweńska, odczyt w PTH, Kraków, listopad 1974).

${ }_{19}$ Jan Diugosz, Historia polonica, t. 3 (Opera omnia, t. 12), ed. Żegota Pauli, Cracoviae 1876,450 . Ks. Wolny sądzi, że motywy Skirgiełły wyszły z kręgu duchownych krakowskich, „którzy już wypracowywali dla królowej koncepcję teologiczną, uzasadniająca podjęcie przez nią decyzji [...] wbrew zawartemu poprzednio układowi małżeńskiemu" - Zagadnienie formacji duchowej królowej Jadwigi, wyktad [...] $w$ bazylice na Wawelu 17 II 1974, „Notificationes e curia metropolitana Cracoviensi" 1974, 64. Niezależnie od tego interesującego przypuszczenia, trzeba pamiętać, że motyw chrztu Litwy był głównym argumentem zarówno strony litewskiej jak polskiej i Skirgiełło musiał go poruszyé bez zapożyczeń tej myśli u Polaków i musiał wskazać na rolę i zasługę królowej, do której mówił, choć zapewne tekst tak ważnego przemówienia został ,,uzgodniony".

20 Długosz, Historia, t. 3, 464. 
pobyt dworu, choć zaraz nagrodzonych. Tradycja ta zapewne prawdziwa w związku z tzw. stacjami dworu, może innej daty, jak gdyby anonsuje u progu działania Jadwigi jej zdolność do poważnej refleksji i jej serce, podbudowuje jej późniejszą charakterystykę.

Nie towarzyszyła jednak królowi w jego pierwszej chrystianizacyjnej pođróży na Litwę ${ }^{21}$. Nie trudno domyślać się, że zbyt cenna była jej osoba, aby ją narażać na trudy, a może i niebezpieczeństwa tej podróży. Ale nasuwa się też przypuszczenie, że działała tu obawa, że złe wrażenie wyırze na młodej i wykwintnej królowej, czułej na łzy ludzkie, brutalny sposób chrystianizowania Litwy, całego narodu, całego państwa. Przymus książęcy, niszczenie starych bogów, miejsc kultu, tępienie obrzędów. Dla niej przeznaczono inną podróż polityczną, wyprawę na Ruś halicką, którą po śmierci Kazimierza Wielkiego przyłączył król Ludwik do Węgier. Kiedy więc mniej więcej równocześnie Jagiełło fundował katedrę w Wilnie 17 lutego 1387, Jadwiga wjeżdżała do Lwowa i wydawała 8 marca przywilej dla miasta ${ }^{22}$. Nie wiemy, co z tych spraw rozumiała i niedorzecznie byłoby uważać ją za wodza wyprawy: to panowie małopolscy postawili ja sobie na czele, aby rewindykować Ruś, o czym mówiono za bezkrólewia na zjeździe sieradzkim, przynagleni zapewne sytuacją na Węgrzech, gdzie Zygmunt Luksemburski byłby się wkrótce jako król węgierski o Ruś halicką upomniał.

Kiedy i jak dowiedziała się królowa Jadwiga, że Elżbietę zamordowało stronnictwo Horvathych, które ją wraz z Marią więziło w zamku Novigrad na poludniu kraju, tego nie wiemy. Ale jeśli trzymać się będziemy koncepcji, że kochano się w rodzinie króla Ludwika i że Jadwidze bliska była matka ${ }^{23}$, to los matki był dla niej prawdziwym nieszczęściem, jednym z ‘ych, które mógł micé na myśli Stanisław ze Skarbimierza, kiedy w mowie na jej pogrzebie wyraził się, że królowa Jadwiga wiele, żyjąc, cierpliw ie i w milczeniu znicsła. Może z tego okresu żałoby po matce pochodzi wiadomość :apisana w krzyżackiej kronice, że Jadwiga widywała gości z zasłoniętą twarzą ${ }^{24}$. Do tego okresu wokół wyprawy ruskiej należą wiadomości o intrygach stronnika Wilhelma, Gniewosza z Dalewic, prowacizonych w stcsunku do króla i królowej, które choć bez wątpienia uciążliwve, musiały mniejszą mieć dla niej wagę niż los matki. Działalność królovej wzrasta, wysuwa się ją do spraw unii, do pośrednictwa między królem, a księciem Witołdem i jego żoną, Witołdem a Skirgiełłą, do porozu-

21 Mimo iż Długosz podaje, że jeździła, lecz wróciła wcześniej [?] (tamże, 466-7).

$\therefore 2$ Kodeks dyplomatyczny katedry $i$ diecezji wileńskiej, t. 1., z. 1., wyd. J. Fijałek, W. Semkowicz, Kraków 1932, 1; Akta grodzkie i ziemskie, t. 3., Lwów 1872,75 .

23 J. Dąbrowski, Ostatnie lata... 34; S. Zakrzewski, art. cyt. Wiadomo, że królowa Elżbieta usiłowała odwlekać wyjazd małej Jadwigi do Polski.

24 Die ältere Hochmeisterchronik, bearb. M. Toeppen, w: Scriptores rerum prussicarum, Bd 3., Leipzig 1866, 609. 
mienia $\mathrm{z}$ siostrą na Węgrzech, aby przeciwdziałała $\mathrm{u}$ męża Zygmunta, wrogiej Polsce akcji politycznej Władysława opolskiego. Bujne i wielostronne życie królewskie otwarło się wokół Jadwigi utalentowanej, pięknej, roztropnej. Bierze w tym życiu udział, przyjmuje gości, dyplomatów, jeździ jak wszyscy na polowania, ma swoje psiarnie, strzelców. Z biegiem lat interesują ją dzieła wychodzące $\mathrm{z}$ wawelskiego Scriptorium, a więc własna biblioteka, dąży do pobożności nowej nie tylko broniącej, ale zalecającej kontakt ze światem, interesuje ją Uniwersytet krakowski. Oczekuje upragnionego dziecka i wraz z nim umiera.

Takie są w największym skrócie losy Jadwigi, owe 15 lat na polskim tronie. W życiu codziennym znajdowała się w pobliżu królowej rodzina Melsztyńskich. Ród ten herbu Leliwa doszedł do znaczenia za Łokietka i Kazimierza Wielkiego, wspierał Andegawenów; za Ludwika rozszczepił się na Melsztyńskich i Tarnowskich. Chrzestną matką króla Jagiełły, obok chrzestnego ojca księcia opolskiego, była Jadwiga z Melsztyńskich Pilecka, wdowa po Ottonie wojewodzie sandomierskim, zwana w źródłach domina Ottonissa ${ }^{25}$. Pochodzenie z domu Melsztyńskich jej rolę zupełnie wyraźnie określa. Była rodzoną siostrą młodego wojewody krakowskiego Spytka, jednego $z$ wybitnych działaczy na rzecz związku z Litwą, wraz z stryjecznymi z Tarnowa, obok Kurozwęckich. Spytek był szczególnie faworyzowany przez króla Jagiełłę, od spotkania w Lublinie począwszy, kiedy przyszły król jechał do Krakowa; królowa Jadwiga obdarzyła Spytka przywilejem wkrótce po przyjeździe do Polski i akt ten możemy również zaliczyć do dokumentów, które rozumiała ze względu na odbiorcę, niewiele od niej starszego, znanego zapewne $\mathrm{z}$ dworu rodziców. Jest więc pani Pilecka jedyną dotąd wiadomą nam matroną, jedną z tych, których poszukujemy przy wjeździe Jadwigi do Polski, które pragnęlibyśmy odnaleźć i poznać, aby przez ich działalność i środowisko poznać rady i sugestie, jakie w królewnę niewątpliwie sączyły, oddane sprawom mężów i braci, a może same zaangażowane w ideę połączenia Litwy z Polską i jej uchrześcijanienia. Tak można sądzić o Pileckiej. Mamy prawo uważać, że ona, siostra faworyzowanego Spytka, wspierała Jadwigę w pierwszych chwilach na Wawelu, gdzie królewnie węgierskiej co najmniej nie było raźno po rozstaniu $\mathrm{z}$ matką, $\mathrm{z}$ atmosferą rodzinnego dworu, ciepłym klimatem

${ }_{25}$ Zbiór najstarszych przywilejów i wilkierzy $m$. Krakowa, wyd. S. Estreicher, Kraków 1936, 14-15. Na pochodzenie Pileckiej po raz pierwszy zwróciła uwagę Gertruda Małaczyńska w art. Jadwiga z Melsztyńskich, księżna opolska, $\dot{z}$. Bernarda, PSB X 300-1. Źródło cytuje Włodzimierz Dworzaczek, Leliwici Tarnowscy, Warszawa 1971. Wybór księcia opolskiego na ojca chrzestnego Jagiełły świadczył nie tylko o tym, że Opolczyk przeszedł na inne pozycje polityczne, ale wskazywał też na wolę królowej węgierskiej, której niedawno był pełnomocnikiem na rzecz Wilhelma. Elżbieta, żona Spytka, z pochodzenia Węgierka, uchodziła za córkę Emeryka Bebeka, starosty Rusi po Opolczyku. Podzielałam to zdanie - zob. Elżbieta Melsztyńska, w: Prace Koła Historyków UJK, Lwów 1929 oraz PSB VI $263-4$. 
Węgier. Zapewne Jadwiga Pilecka przeciwstawiała się po odjeździe księcia Wilhelma z Krakowa, istniejącej niewątpliwie wokół Jadwigi, niespokojnej, dworskiej kobiecej agitacji — za i przeciw Jagielle. Spośród młodego pokolenia wysuwa się na czoło kobiecego otoczenia Jadwigi druga Melsztyńska, żona wojewody Spytka, córka magnackiej rodziny węgierskiej, zapewne rówieśnica królowej i przybyła z nią panna dworska. Obie one przez całe życie Jadwigi były przy niej w Polsce, w Krakowie. Pilecka zmarła w r. 1406, Elżbieta aż w połowie XV w., już jako księżna śląska na Ziembicach, owdowiawszy wcześnie po Spytku, który zginął nad Worsklą (latem 1399). Ottonissa, starsza niewątpliwie, wprowadzała Jadwigę, Elżbieta jako młodsza towarzyszyła jej zapewne w życiu codziennym ${ }^{26}$.

Jeżeli idzie o krąg polityków, mężów stanu, musimy pamiętać, że w pobliżu Jadwigi od pierwszych jej chwil w Krakowie znajdował się biskup krakowski Jan z Radliczyc zwany Radlica. Na jego to zapewne ręce ofiarowała, przekraczając po raz pierwszy próg katedry krakowskiej, a może z okazji swej koronacji, kosztowne naczynie z kryształu i złota, ozdobione herbami Węgier i Polski, z napisem łacińskim, którego ostatnie tłumaczenie wskazuje na apel do Matki Boskiej. Radlica może był tym spośród rady królowej, który poddał królowej pierwsze uposażenie ołtarza w katedrze, mając i osobiste nabożeństwo i jako biskup najlepsze rozeznanie w potrzebach altarystów. Działalność Radlicy u boku królowej nie jest nam znana $\mathrm{z}$ jakichś bezpośrednich przekazów, a jednak musimy ją przyjąć jako pewnik i ze względu na państwowe i kościelne stanowiska, jakie posiadał, i ze względu na to kim był. Przywykliśmy łączyć z Jadwigą dopiero działalność następcy Radlicy, Piotra Wysza, ponieważ o Wyszu ${ }^{27}$ wiemy nieporównanie więcej niż o Radlicy. Nie można jednak zwątpić, czy i o Radlicy nie zdobędziemy kiedyś nowych wiadomości, skoro np. afirmację jego roli dookoła odnowy Uniwersytetu w Krakowie, czego mieliśmy prawo tylko domyślać się ${ }^{28}$, przyniosła niespodziewanie niedawno ogłoszona mowa uniwersytecka.

26 Tamże; A. Strzelecka, O królowej Jadwidze, studia $i$ przyczynki, Lwów $1933,66,84$.

27 Stanisław Kijak (Piotr Wysz, biskup krakowski, Kraków 1933) miał prawo sądzić, że ,w ostatnich trzech latach [?] swego życia królowa Jadwiga [...] zbliżyła się więcej" do swego zaufanego otoczenia [...]. W tym gronie, gdzie niepoślednie miejsce Piotr zajmował, powstała myśl odnowienia uniwersytetu w Krakowie". Dzięki odkrytej mowie Bartłomieja z Jasła wiemy, że działo się to kilka lat wcześniej i że poprzedni biskup krakowski Radlica wysuwał się tu wraz z królem na pierwsze miejsce - zob. M. Gębarowicz, Psałterz floriański... To piękne studium wielkiego erudyty przyniosło, obok dyskusyjnych hipotez dotyczących $\mathrm{m}$. in. Piotra Wysza, nowe, bezsporne poszerzenie wiadomości o nim. Najnowsze odczytanie napisu na kielichu Jadwigi dał Oskar Halecki, Un appel d'Hedvige d'Anjou à la reine des cieux, „Antemurale” 16 (1972).

${ }_{28}$ Radlicy, wybitnemu przyrodnikowi-lekarzowi, zapewne zależało na zainteresowaniu króla i królowej sprawą uniwersytetu i to chyba wcześniej nim w oto- 
Wiemy, że był uczonym przyrodnikiem, wybitnym lekarzem wykształconym w Paryżu i Montpellier, poleconym przez króla Francji królowi węgierskiemu Ludwikowi, którego został lekarzem nadwornym. Król powierzył mu kolejno urząd kanclerza w Polsce, następnie, kiedy czuł się chory, współrządy w swoim zastępstwie wraz z Kurozwęckimi ra terenie Polski. Wreszcie kiedy zawakowało, obdarzył go biskupstwem krakowskim w r. 1382, na krótko przed swą śmiercią ${ }^{29}$. Kiedy powoływano zjazdy i toczyły się pertraktacje dotyczące objęcia tronu przez Andegawenkę, wkrótce imiennie przez Jadwigę, Radlica był i współregentem i biskupem krakowskim. Na jego ręce i kilku innych dostojników małopolskich już dn. 25 XI 1382 r. w Radomsku złożyli Wielkopolanie przyrzeczenie, że tej królewnie węgierskiej dotrzymają wierności, która zamieszka wraz z mężem w Polsce ${ }^{30}$. Od samego więc początku wydarzeń w Polsce po śmierci króla Ludwika znał Radlica kierunek polskiej polityki (sprzeciw unii personalnej z Węgrami, niechęć do Zygmunta czy Wilhelma), ale nie ma żadnych danych, aby przykładał specjalnie rękę do zmiany zarządzeń Ludwika, których nie tylko efekty, ale i tajniki znał również. Problemy chrztu Litwy i jako biskupowi i jako Wielkopolaninowi były mu niewątpliwie bliskie i ważne. Ale był też jedną ze znanych Jadwidze osób z dworu rodziców, znał zapewne język węgierski. I chociaż trudno mówić o jakiejś zażyłości między dzieckiem królewskim a poważnym dostojnikiem, o poufnych rozmowach, można się domyślać, że królewna wprost lub pośrednio szukała u niego opieki i rady. Nie mógi nie wiedzieć, jak i inni panowie rządzący, o spotkaniach orszaków dziecięcych u krakowskich franciszkanów, liczących się niewątpliwie z biskupem. Nie on jednak według tradycji Długoszowej zatrzymał Jadwigę u furty wawelskiej, ale podskarbi Dymitr. Nieobcy natomiast musiał być Radlica odwołaniu ślubów haimburskich w katedrze wawelskiej. Działał jakby w cieniu, niejedną trudną przeżył sytuację. Do tych zapewne okoliczności m. in. odnosi się interesujący element charakterystyki Radlicy w Żywotach biskupów u Długosza, że „wiele on cierpliwością umiał osiągnąć”. $\mathrm{Na}$ Litwę w podróży chrystianizacyjnej nie jeździł, zapewne nie powinien

czeniu Jadwigi i Jagiełły doszli do głosu głównie działacze kościelni związani z uniwersytetem praskim. Niespełna 10 lat później, w r. 1400, w renowacyjnym akcie króla dla uniwersytetu znalazła się pochwała dla środowiska uniwersyteckiego w Paryżu, dobrze znanego Janowi - por. A. Strzelecka, Jan z Radliczyc $z w$. Radlica, PSB X 469-72. J. Wolny jest zdania, że Radlica wysunąl się na pierwsze miejsce $\mathrm{w}$ otoczeniu Jadwigi - art. cyt.

29 J. Dąbrowski, Ostatnie lata..., 29; Aleksander Gieysztor, Mistrzowie polscy uniwersytetu paryskiego $w$ XIV $i X V w$., w: Wieki średnie. Prace ofiarowane Tadeuszowi Manteufflowi, Warszawa 1962.

30 Przyrzeczenie wielkopolan, w: Kodeks dyplomatyczny wielkopolski, t. 3., Poznań 1879, 527-9. Obok Radlicy występowali m. in. kasztelan krakowski Dobiesław Kurozwęcki, wojewoda Spytek Melsztyński, wojewoda sandomierski Jan Tarnowski i kasztelan wojnicki Jan Tęczyński. Zob. Maciejewska, dz. cyt., 21. 
był opuszczać Krakowa, mamy z tego czasu dokumentalne dowody jego ciziałalności w diecezji. Jaki był początkowo stosunek Jagiełły do biskupa, tego nie wiemy, króla chrzcił arcybiskup, Radlica zaś jego braci. Nie wiemy więc, czy ogromne nadanie Muszyny z przyległymi wsiami w r. $1391^{31}$ dla biskupstwa krakowskiego jest kontynuacją dobrych od razu stosunków między Jagiełłą a Radlicą, czy też oznacza jakiś przełom w tych stosunkach na ich korzyść i jest dowodem wdzięczności za przychylną opiekę nad pierwszymi latami Jagiełły w Krakowie, oczywiście $\mathrm{w}$ sensie politycznym. Prawie równocześnie z nadaniem Muszyny 30 VIII 1391 królowa ufundowała ołtarz św. Anny w katedrze, a król tę fundację potwierdził. Duże królewskie nadanie świadczy, że biskup oddał mu jakieś znaczne usługi, narażając się, jak można sądzić, w służbie państwa. Na 3 lata przed śmiercią, a więc około 1389 r. usiłowano Radlicę otruć na śniadaniu u proboszcza św. Floriana w Krakowie, a z konieczności czy przypadku otruto innych obecnych, podczas gdy eximius doctor zdołał się wyratować ${ }^{32}$. Kto tu działał? Wróg wewnętrzny książę opolski czy Krzyżacy, którzy mieli długie ręce? Przeciwstawienie się każdej z łych grup mogło wzbudzić i wzbudziło uznanie królewskie. Długosz milczy o przyczynie i poszlakach trucia biskupa, inne źródła o tym nie wspominają.

W pobliże dworu Jadwigi i Jagiełły wnosił więc Radlica ową zażyłość z jej rodzicami, a także elementy romańskie swej umysłowości, wynikające $\mathrm{z}$ wieloletniego pobytu we Francji, a zawsze przez Andegawenów wegierskich wysoko cenione, nieobce Jadwidze. Był mądry, rzetelny, doskonały lekarz, żadnego zarzutu nie stawia mu Długosz, któremu nie brak krytycyzmu w stosunku do duchownych, zwłaszcza wysoko postawionych. W mądrym i uczonym Radlicy powinniśmy także widzieć pierwszego inspiratora zainteresowań Jagiełły i Jadwigi odnową Uniwersytetu Krakowskiego; kaznodzieja uniwersytecki wymienił go 4 XII 1390 r. ${ }^{33}$, obok króla, jako główną ,,przyczynę sprawczą" tych poczynań, niewątpliwie istniejących już dawniej, zanim przystąpiono do otwarcia roku akademickiego, z którego pochodzi mowa. Kto wie, jak dawne były te zamiary odnowy; przeszkadzała ich realizacji sytuacja polityczna za Ludwika, jego zajęcie się omal wyłącznie sprawami sukcesji córek, następnie uciążliwe bezkrólewie. Radlica przewodniczył niewątpliwie grupie intelektualnej krakowskiej, do której należał i jego oficjał Nawój z Tęczyna, a więc można rodzina Tęczyńskich, i obie panie Melsztyńskie; grupa ta była zarazem otoczeniem i towarzystwem królowej Jadwigi.

31 O nadaniu Muszyny - zob. Kodeks dypl. katedry krak., 161; tamże, 162 akty królowej i króla dotyczące fundacji ołtarza św. Anny w Katedrze.

32 Dlugosz, Vitae episcoporum Poloniae, Opera I.

33 M. Kowalczyk, Odnowienie uniwersytetu krakowskiego w świetle mów Bartıomieja z Jasła, „Malopolskie Studia Historyczne” 6 (1963) z. 3-4, 31 n. 
Obie Melsztyńskie zostały później zapisane jako dobrodziejki uniwersytetu, jako taka przeszła do historii Konstancja Koniecpolska ${ }^{34}$, domina Kochna, jak ją nazwał Jan Elgot w korespondencji - może Czochna z Rachunków dworu Jadwigi? Grupa ta o wiele liczniejsza oczywiście niż tu wymienione osoby, za mało jest znana. Wśród napięć politycznych, wojen toczonych z Opolczykiem, w atmosferze zbrojnej i dyplomatycznej pomocy Litwie, nie zaniedbywała w Krakowie Uniwersytetu, jego odnowy. Działalność taka ujawniła się jasno w owej mowie uniwersyteckiej Bartłomieja z Jasła z 4 XII 1390 r. Główną ,,przyczyną sprawczą" został król nazwany, co gdyby nawet było częściowo zwrotem kurtuazyjnym, musi też dowodzić co najmniej zrozumienia przez Jagiełłę wskazanego mu problemu, o ile sam nie zainicjował dociekań, co dzieje się z założonym przez Kazimierza Wielkiego Uniwersytetem i konsekwentnie nim się zainteresował, w oparciu o krakowskie grono elitarne z biskupem na czele. Równie kurtuazyjny, ale uprawdopodobniony jest argument w zwrocie mówcy do króla, że za młodu uciążliwe rządy i wojny nie pozwoliły Jagielle zająć się sprawami nauki, co właśnie teraz pragnie nadrobić. Uniwersytetu pragnęli, zdaniem mówcy, wszyscy, bogaci, biedni, mieszczanie, rycerze, kobiety. Niestety niedługo mógł pracować nad dziełem ożywienia Uniwersytetu uczony przyrodnik, biskup krakowski. Zmarł w r. 1392, być może trucizna podkopała mu zdrowie. Jedną jeszcze wskazówkę zostawił prawdopodobnie królowej w swej trosce o katedrę: dbałość o los wikariuszy katedralnych.

We wspomnianej mowie Bartłomiej nie mówił o roli szesnastoletniej królowej w sprawie Uniwersytetu, wyraził się natomiast, że niektórych osób nie wymienia, aby go nie posądzono o pochlebstwo. Może więc miał tu na myśli królowę, coraz intensywniej wprowadzaną w sprawy państwa? Sądzę, że na swego następcę wskazał Piotra Wysza nikt inny jak Radlica, o czym może nawet świadczyć zdecydowane poparcie, jakie dali oboje królestwo na to stanowisku Wyszowi. Wysz był teologiem, również wykształconym za granicą, w Padwie, Wielkopolaninem jak Radlica, miał swe stosunki w Rzymie, których na pewno nie osiągnął bez polecenia swego biskupa krakowskiego. Ambitny, czynny dyplomata i polityk w negocjacjach z Krzyżakami, zainteresowany był również odnowieniem Uniwersytetu w Krakowie, a zwłaszcza poszerzeniem go o ważny Wydział Teologiczny, którego brakowało Akademii krakowskiej ${ }^{35}$. Zwracano nieraz uwage, w dyskusjach historycz-

34 A. Strzelecka, Koniecpolska Konstancja, PSB XIII 510.

35 Było to główną zasługą Wysza wobec uniwersytetu i z tym Wydziałem należy, moim zdaniem, łączyć pośmiertne kazanie o Wyszu Franciszka z Brzegu, które wydaje się cokolwiek bałamutne. Zostało ono przerobione z kazania Stanisława ze Skarbimierza na inny pogrzeb; na marginesie autor dopisał $\mathrm{m}$. in. wzmiankę o zaintersowaniu Wysza Uniwersytetem, ,że to właśnie na skutek próśb i na- 
nych, dlaczego to $\mathrm{w}$ trakcie starań o ten Wydział, a nawet w tym samym 1397 roku, kiedy papieskie zezwolenie nadeszło, toczyły się układy o Kolegium przy Uniwersytecie w Pradze dla kształcenia Litwinów, którego fundatorką stała się królowa Jadwiga. Na pewno działały wtedy rozmaite siły, których nie da się obecnie jeszcze wyjaśnić. Być może, że Radlica, pierwszy kanclerz wznowionego Uniwersytetu, jak nazwał go Bartłomiej, ów eximius medicinae doctor, który od jednego spojrzenia rozpoznawał chorobę, nie przykładał specjalnej wagi do teologii w Krakowie, skoro była wysoko rozwinięta blisko, w czeskiej Pradze, może pragnął, aby wydziały Uniwersytetu Krakowskiego okrzepły tak, jak były założone przez króla Kazimierza, na teologię miał przyjść czas, aby mogła dorównać Pradze czy Sorbonie. W każdym razie nie wystarcza przypuszczenie, że przy tym Kolegium pragnął zabezpieczyć sobie przyszłość pośrednik w jego ufundowaniu głośny czeski uczony, Jan Štěkna. Pamiętajmy, że Jadwiga utrzymywała z czeskimi uczonymi zażyłe stosunki, a przede wszystkim pojawili się w kręgu jej dworu Polacy, wykształceni w Pradze. Opowiada Ludolf z Żagania, Długosz, a także włączone do Historii Długosza rymowane wspomnienie poświęcone królowej, że otaczała się uczonymi, że ich sprowadzała spoza Polski. Wielu spośród nich dałoby się wymienić imiennie, jak samego Bartłomieja, czy Stanisława ze Skarbimierza - i co najmniej trzech Czechów: Jana Isnera, Hieronima Sylwana z Pragi, spowiednika Jagiełly, któremu król wystawił klasztor premonstrantów w Sączu, i właśnie Stěknę. Przyjechał on do Krakowa zapewne w r. 1394, w orszaku margrabiego Prokopa, posła od króla Wacława do Jagiełły i Jadwigi ${ }^{36}$. Nastał odpowiedni moment polityczny, Stěkna został w Polsce nagrodzony widać za usługi w poselstwie Prokopa kapelaństwem królowej i probostwem w Przemankowie. Nie ulega wątpliwości, że czescy uczeni gromadzili się na dworze krakowskim dookoła królowej głównie dla celów katechizacji króla. Jagiełło po latach przypomniał tę rolę przedstawicielom czeskim, kiedy przyjechali na Wawel, aby dyskutować o nauce Husa, zwracając się do nich z uwagą, że „uczyli go kiedyś katolickiej wiary”. Nic więc dziwnego, że w tej krakowskiej atmosferze końca XIV w., kiedy Czesi uczyli króla nowej religii, sami reprezentując znakomity Uniwersytet Karola w Pra-

\footnotetext{
mów Wysza Jadwiga nakłoniła Jagiełłę, by odnowił Uniwersytet Krakowski, który założony za Kazimierza Wielkiego, upadł po jego śmierci" (M. Kowalczyk, Krakowskie mowy uniwersyteckie..., 122-3). Jak wiemy, już poprzedni biskup krakowski Radlica zająl się odnową Uniwersytetu, zainteresowując tym króla. Wysz był kontynuatorem Radlicy, co $\mathrm{w}$ ciągu tych lat zatarło się $\mathrm{w}$ pamięci ludzkiej.

36 Celina Zawodzińska, Kolegium królowej Jadwigi przy Uniwersytecie Karola $w$ Pradze $i$ jego pierwszy statut [1411], ,Zeszyty Naukowe UJ. Prace historyczne” nr 9 (1962); A. Strzelecka, Ze studiów nad stosunkami polsko-czeskimi za Wacława IV $i$ Władysława Jagiełty, „Małopolskie Studia Historyczne” 8 (1965) 52-3 n. Margrabia Prokop pojawił się w marcu 1394 r. na dworze polskim, w listopadzie również spotykamy poselstwo czeskie. - Rachunki... jw.
} 
dze, zwrócono się ze strony polskiej, zwróciła się królowa do króla czeskiego Wacława IV, którego przyjaźń była w dodatku bardzo cenna, choćby ze względu na Krzyżaków i młodszego Luksemburga Zygmunta, o możność utworzenia Kolegium dla Litwinów, którzy kształciliby się w Pradze. Nie wiedziano, czy szybko rozwinie się świeżo uzyskany Wydział Teologiczny i cały Uniwersytet Krakowski wchodzący dopiero w okres Jagiellońskiego odnowienia. Piękna arenga, jaką zapewne Štěkna wybrał dla aktu fundacyjnego bursy praskiej, oznajmia, że królowa wiele nocy spędziła rozmyślając, jak uchrześcijanić ochrzczoną Litwę.

Taki obraz odpowiadał już widocznie wtedy w r. 1397 usposobieniu dwudziestotrzyletniej królowej. By sprostać swym zadaniom, wspierała swe czynne życie skupieniem, kontemplacją. Napisałam przed laty, co niedawno doczekało się rozwinięcia, a zwłaszcza podbudowania w sposób ze wszech miar godny uznania ${ }^{37}$ : ,nie ograniczała się do miłosiernych uczynków, fundacyj, co było ogólnie praktykowane jako oznaka pobożności ludzi zamożnych, ani też do postów, a nawet do uczestniczenia w nabożeństwach i przestrzegania przepisów Kościoła [...] W religii szukała widocznie odpowiedzi i wskazówek na codzienne zagadnienia, nie chcąc poprzestać na spełnianiu praktyk. Szła z zasadami swej wiary przez życie, nie zamykając się $\mathrm{z}$ niemi w celi". Prąd połączenia życia wewnętrznego z życiem czynnym, praktycznym, rozwijał się właśnie w Europie pod koniec XIV w. Ku temu prądowi, ku takiej religijności skierowała się królowa Jadwiga.

Czynną religijność Jadwigi, ideał jej czasów, znamy nie tylko z badań nad jej życiem, ale mamy ją poświadczoną współcześnie, jasno i dobitnie, co rzadko da się stwierdzić jeśli idzie o charakterystyki królowych. Również uczeń praski Henryk Bitterfeld z Brzegu, o którym nie wiemy czy był kiedykolwiek w Krakowie, zadedykował królowej Jadwidze książkę rękopiśmienną, traktat De contemplatione et vita activa. Sam tytuł dedykowanej książki jest wymowny. Ale, co więcej, Bitterfeld pisze, że poświęca jej tę pracę, ponieważ „słyszał”, że pragnie ona osiągnąć ,,szczyty pobożności” (apicem devotionis). Widzi ją jako Martę czynną i Marię kontemplującą, ten sposób życia afirmuje, doradza jej ${ }^{38}$.

Motyw dwu splecionych MM, powtarzający się na murze komnaty na Wawelu, w Psałterzu floriańskim, który dla niej spisano, na kryształowym dzbanku, który ofiarowała biskupowi Radlicy, nazwano w nauce dewizą Jadwigi (Zofia Budkowa, Mieczysław Gębarowicz). W świetle dedykacji Bitterfelda rozwiązanie Maria i Marta jest bardzo prawdopodobne (Gębarowicz, Nowa Sztuka, 1939) zwłaszcza, że dwie te postacie

37 J. Wolny, art. cyt.

38 Dedykacja drukowana jest w: Codex epistolaris saec. XV, 145-7; zob. Strzelecka, O królowej Jadwidze..., 85-9. 
ewangeliczne występują często, w owym wieku łączenia życia kontemplacyjnego $\mathrm{z}$ czynnym, $\mathrm{m}$. in. zarówno $\mathrm{w}$ korespondencji papieża jak w kazaniach Husa. Mistrz Henryk Bitterfeld był z kręgu działaczy reformy wewnętrzno-kościelnej. To co wie o Jadwidze, że dąży do szczytów pobożności, charakteryzuje nam ją w pełni z czasu, kiedy żyła i działała, stanowi podbudowę pod charakterystykę pośmiertną, którą zawdzięczamy duchowieństwu krakowskiemu w Kalendarzu - może Bartłomiejowi z Jasła (sugestia M. Kowalczyk) - gdzie ją nazwano omnium virtutum pedisequa ${ }^{39}$.

$\mathrm{Na}$ tej drodze życia czynnego i kontemplacyjnego zarazem, służyły też królowej niewątpliwie wzory współczesne, bliższe w czasie niż Maria i Marta. Myślę zwłaszcza o św. Brygidzie szwedzkiej, matce licznych dzieci, czynnej w świecie i świętej. Jej pisma tłumaczone w Scriptorium na Wawelu ${ }^{40}$ może służyły za lekture $w$ gronie dworu, niekoniecznie tylko kobiecego; na orientacji bowiem Jadwigi w sprawach krzyżackich zaważyła na pewno Brygida, która Krzyżaków gromiła. Przy pomocy jej wypowiedzi, nie gorzej zapewne niż akcją polskiej dyplomacji, objaśniano Jadwidze stosunki z Krzyżakami. Krzyżacy zorientowawszy się, że Jadwiga przedstawia wobec nich wyłącznie polską i litewską rację stanu i że nie odciągną jej z tej drogi, przestali respektować spotkania. Nic więc dziwnego, że powiedziała komturowi toruńskiemu, którego w. mistrz przysłał w swoim zastępstwie, że po jej śmierci nie unikną wojny z polską.

Swój kult dla św. Brygidy ${ }^{41}$ upamiętniła ostatnią fundacją w katedrze, a mianowicie ołtarzem pod jej wezwaniem (i św. Erazma). Pod koniec umiłowane życie czynne odchodziło na dalszy plan, czuła się źle, myślała o śmierci.

39 Kalendarz krakowski (Monum. Pol. hist., t. 2), Lwów 1872, 934. J. Wolny zdaje się opowiadać za tym, że duchowni w Krakowie formowali według napisanego specjalnie dla Jadwigi Traktatu Bitterfelda jej osobowość niemal od jej przyjazdu. Gębarowicz przypisuje tę rolę, a także rolę inspiratora traktatu wyłącznie Piotrowi Wyszowi. Pojmowaniu Wysza jako „edukatora" przeciwstawił się ostro Halecki (art. cyt.) nie zaprzeczając, że mógł on być redaktorem całości traktatu. Sądzę, że kiedy Jadwiga zasłynęła jako zarazem pobożna i czynna, otrzymała Traktat Bitterfelda w holdzie. Nie myli się Halecki (art. cyt. 59): ,il est donc une erreur prétendre que cette activité de la reine ne se manifesta que dans les deux dernières années de sa vie et que Wysz devait lui apprendre à concilier la contemplation et la vie active".

40 M. Kowalczyk, Bartłomiej z Jasła, „Materiały i Studia Zakładu Historii Filozofii" 5 (1964).

${ }_{41}$ Zob. PSB X 291-97 i Hagiografia polska I 485-523. To nabożeństwo nie tylko do polskich księżnych, jak Jadwiga śląska czy Kinga, ale i do Brygidy sūwedzkiej, znalazło wyraz $w$ obrazach umieszczonych na tryptyku, w którym był zamknięty prawdopodobnie już pod koniec XV w. wawelski krucyfiks. Na tryptyku znajdowały się wszystkie trzy księżne oraz królowa Jadwiga. Wnikliwy wywód oparty także na archiwaliach poświęcił tryptykowi ks. Czesław Skowron w odczycie wygłoszonym na posiedzeniu Komisji Historii Sztuki PAN w Krakowie 13 XII 1974 r. 


\section{QUELQUES DÉTAILS CONCERNANT LA BIOGRAPHIE DE LA REINE HEDVIGE}

\section{R és u mé}

On commémore généralement l'anniversaire de la mort de la reine Hedvige (17 VII 1399). Les sources hongroises n'ont pas noté la date de sa naissance. Cependant, à la suite des recherches de J. Dąbrowski et de l'analyse des notes du Calendrier de Cracovie, on a pu fixer cette date, avec une très grande vraisemblance, au 18 février 1374. Ceci permet d'affirmer que, lors de son arrivée en Pologne, Hedvige n'était encore qu'un enfant. Ce n'est qu'ici, à Cracovie, que d'enfant de souche royale elle devint une reine vénérée, pleine de mérite et candidate à être portée sur les autels.

L'article considère Hedvige sous un double aspect; il traite de sa vie et explique comment, en ces conditions, s'était développée sa personnalité.

Dès son enfance Hedvige était destinée à épouser Wilhelm de Habsbourg et devait régner en Autriche, puis en Hongrie. Mais, vers la fin de 1384, elle arrive en Pologne où on lui désigne pour mari Jagellon. Il est permis de supposer que, pour cette jeune fille de douze ans, l'obligation de renoncer à son premier fiancé n'a pas été aussi tragique qu'on avait coutume de la décrire. Le sentiment qu'elle pouvait éprouver dépendait bien plus de ses rapports avec sa mère et de la volonté de celle-ci que de la personne de Wilhelm ou de Jagellon. Le fait d'amoindrir le drame d'Hedvige en 1385/86 ne diminue en rien sa sainteté qui apparaît et brille dans ce qu'Hedvige est sciemment devenue au cours des ans - et non pas dans les débats politiques auxquels l'enfant ne pouvait rien comprendre.

Au milieu des affaires qui se déroulaient autour de la toute jeune reine, c'est la mort tragique de sa mère qu'elle a dû profondément ressentir. La matrone de son entourage était alors Hedvige de Melsztyn Pilecka. Parmi les personnes de la jeune génération, c'est Hedvige Melsztyńska, épouse de Spytek, voïevode de Cracovie, qui occupe le premier rang. Quant aux hommes politiques, au milieu desquels grandissait la reine Hedvige, il faut citer en premier lieu Jean de Radliczyce, dit Radica, évêque de Cracovie. C'est en lui que nous devrions voir celui qui le premier inspira la rénovation de l'Université de Cracovie. Hedvige s'entourait volontiers de savants, parmi lesquels se trouvaient de nombreux Tchèques.

Menant une vie très active, toujours la première à la cour, douée d'un charme exceptionnel, prenant une part active à la politique et la diplomatie, songeant à christianiser la Lituanie, Hedvige savait cependant se concentrer et s'adonner à la contemplation. Elle vivait selon les principes de sa foi. Au milieu de femmes éclairées et sous le patronat des savants évêques de Cracovie, elle a atteint à la cour de Pologne une religiosité peu ordinaire. C'est cette attitude de Marthe et de Marie que souligne, affirme et conseille Henri Bitterfeld de Brzeg en dédiant à Hedvige son traité De contemplatione et vita activa. Dans cette vie active et contemplative, la reine suivait des modèles contemporains et notamment celui de ste Brgitte de Suède. 